\title{
The Change of Architectural Characteristic on Megalithic Todo Village Based on Periodization
}

\author{
Antariksa $^{1 *}$, Dezzalina Dyana Paramita ${ }^{2}$ \\ ${ }^{1,2}$ Department of Architecture, Faculty of Engineering, Universitas Brawijaya, Malang-Indonesia. \\ *Corresponding author. Email: antariksa@ub.ac.id
}

\begin{abstract}
Not many people know that Todo is one of the megalithic villages that was the center of the Manggarai Kingdom in the past. The stories contained in the literature always mention Todo as the forerunner of the emergence of Manggarai residents. Like other Manggarai megalithic settlements, Kampung Todo is composed of supporting elements such as rags, farts from, funerals and likes. However, over time, modernization has entered into it and has slightly changed the face of these village settlements. These changes were identified in three periods, namely the Initial Period, the Dutch Population Period, and the Reconstruction Period. This study aims to determine the extent of settlement development in Kampung Todo in each period. Based on these backgrounds and problems, the research method used in this study is the ethnographic method by studying the culture of the local community followed by analyzing these settlements based on a stylistic system, physical system, and spatial system. The next stage continued with interviews with the surrounding community and customary stakeholders to obtain supporting data. From these results, it was found that the settlement underwent changes and developments in terms of function, dimensions, material, spatial patterns and character, and others.
\end{abstract}

Keywords: Settlement development, periodization, change of character

\section{INTRODUCTION}

It is undeniable that progress has led to changes and shifts in traditions, culture, and social order, including the rural areas of East Nusa Tenggara. The change occurred due to the opening of remote villages discovered as a result of development, including Todo Village. Todo village itself, according to its pedigree, is one of the megalithic villages that became the center of the Manggarai Kingdom in the past. The stories mentioned in the literature always say that Todo as the forerunner of the emergence of Manggarai residents. With how the village is open for all circles, their knowledge gradually increased with new things from outside. It will have an impact on the habits of the Todo people and cause a shift in the existing cultural values. This shift in cultural values will also affect the value of architecture. In this case, the traditional architecture will shift and develop into a more modern architecture where the buildings of Kampung Todo in the past were only presented for supplementary materials that fulfill the visual needs of local architecture only. For this reason, the research was conducted as a study of changes in the architecture of Kampung Todo. The research also aims to determine the extent of the development of settlements in Kampung Todo.

\subsection{History of Kampung Todo}

Based on interviews from the key person, in the Todo Village community, there are oral cultural traditions handed down from generation to generation, which tell us that their ancestors came from Malay who migrated to South Sulawesi through Java. The reason for the move was because at that time, Malacca Malays were being controlled by the Portuguese so that traders in Malacca could not trade and move them eastward just as the Kingdom of Gowa was developing. The population moved from Sumatra to Java and then to South Sulawesi about 50-100 years later after mixing with other tribes. After that, the journey continues to the Manggarai area, which at that time was named Nuca Lale. That said, in Nuca Lale that there are four kingdoms named Todo, Bajo, Cibal, and Reok, which they call Adak. From this, they compete and show strength. The most intense competition is Adak Todo with Adak Cibal. As a result, Adak Cibal suffered defeat; thus, de facto, Manggarai was under the control of Adak Todo [1]. Then there was a change of status from Adak to a kingdom. Since that time, Manggarai was under one kingdom called the Manggarai Kingdom. 


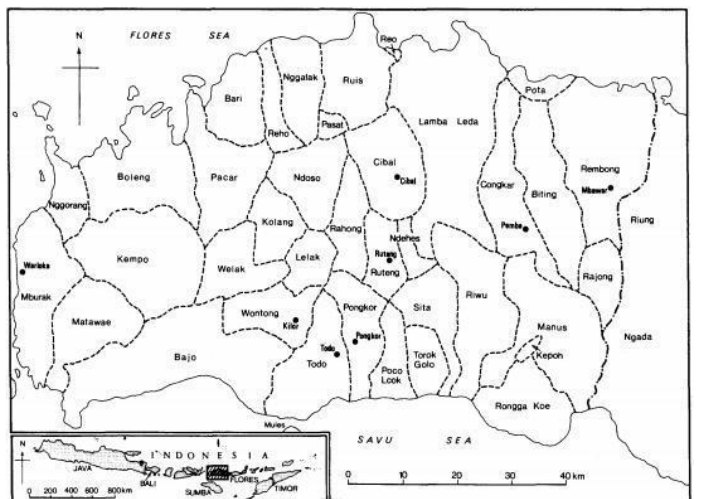

Figure 1 Manggarai's road maps Source: Erb [2]

\subsection{The Development of Todo Village}

During its development, Todo Village was divided into three periods, namely the early period (the 1750s), the Dutch Population period (1907-1990), and Reconstruction (1990-present). The initial period was identified since the victory of Adak Todo in 1750 but was finally destroyed by fire in the year of 1960 and left a few new structures. Mbaru Niang, which was initially a communal house for Todo people, was torn down and replaced with smaller houses [2]. In 1990, access to the village from the main road began to be built. With the opening of access to Todo Village, the existence of Todo is increasingly known by the surrounding community so that the desire to rebuild the Mbaru Niang Todo began around 1990. The first construction was carried out by Maribeth Erb in 1993, and its development continues until this day [2].

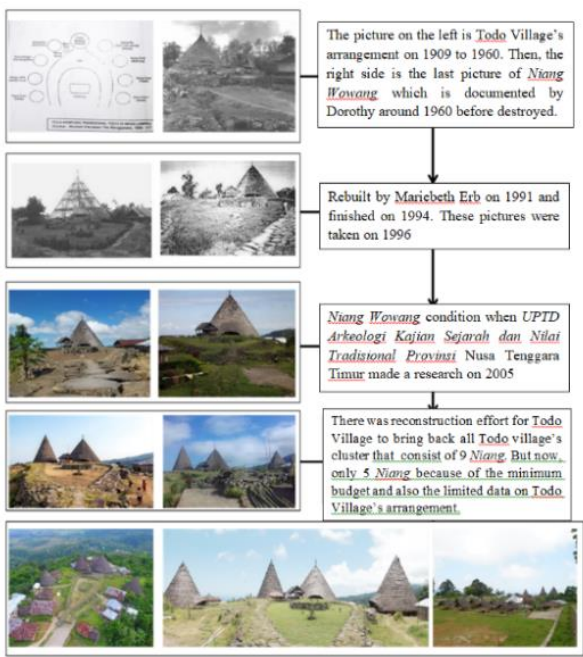

Figure 2 Todo Village's development

\subsection{Architectural Characteristic Todo Village based on its development}

With the period that was published earlier, there were interesting changes in each period [3]. There are three ways to find out the differences in the character of architectural forms in each period:

a. The stylistic system: related to the form of a settlement or the appearance of the building, for example, building typology.

b. The physical system: composition through the characteristics of its components, namely the material forming the structure of space.

c. The spatial system: related to the character of space and how the relationship between the spaces with surrounding elements.

\section{RESULT AND DISCUSSION}

Todo Village is one of 11 villages located in the Satar Mese Utara District, Manggarai Regency. Satar District is determined based on the Regional Regulation of Manggarai Regency Number 08 Year 2015 and is an expansion of the West Satar Mese District. Based on the Regional Regulation, on 31 August 2015, the Manggarai district head inaugurated the North Satar Mese District. The village is bordered by Lelak Subdistrict and Ruteng Subdistrict in the North, West Satar Mese Subdistrict in the South, Satar Mese Subdistrict in the East, and Weri Pateng, West Manggarai Regency in the West. Todo Village is located 30 kilometers from the capital of the Manggarai Regency, namely Ruteng with the boundary of Gulung Village in the west, Popo Village in the north, Renda Village in the south, and Mount Poco Mandasawu in the East. It has an area of 513 hectares and is surrounded by forests.

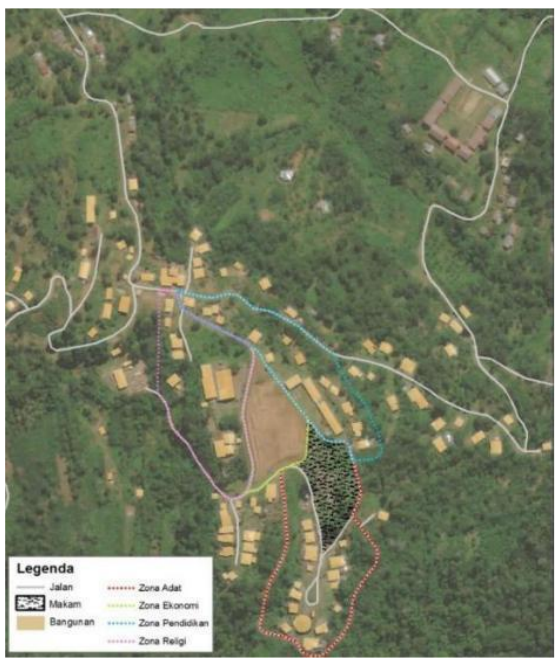

Figure 3 Todo Village's maps

Source: processed from Google Maps 


\subsection{Changes in the Architecture Character of Todo Village}

The house order in the early period consisted of ten traditional houses that were integrated with different functions which were divided into:

1. Niang Wowang, functions as Adak Chairperson

2. Niang Lodok, functions as domestic government affairs

3. Niang Keka, functions as a foreign government affair

4. Niang Rato, functions in security and defense matters

5. Niang Mongko, functions as a place for deliberation of all decisions

6. Niang Toto Bicar, as a shelter for all people's problems

7. Niang Dopo, functions as a legal justice institution

8. Niang Asi, as reporting for a royal reception

9. Niang Macang, to handle household affairs for adak

10. Niang Teruk, as a representative institution of dalu and rabid

Then during the Dutch settlement, the destruction of houses in Manggarai emerged due to poor ventilation and unhealthy conditions of large houses that caused the deadly virus in 1918, which destroyed a quarter of the Manggarai population. However, the house of the Todo clan (Niang Wowang) was allowed to stand because it was considered a resident of the royal family and a cultural symbol of Manggarai. The burned traditional houses did not necessarily disappear but were replaced by small houses to mark the location of the Mbaru Niang in the past. It is why when Dorothy Pelzer, the architect, visited Todo in the early 1960s, only Niang Wowang was still standing. However, a few years after his visit, these houses collapsed and were demolished.

When the road was finished in the reconstruction period, people from Todo began planning to rebuild their large clan house. In 1993, Maribeth Erb documented the redevelopment of Niang Wowang, which was finally completed in 1994 [2]. The addition of new niang occurred after 2005 to 2016, and there were five Mbaru Niang and will continue to grow to their first amount. Even from its scope, the settlement of Todo Village has developed, and the dimensions of the settlement will widen.

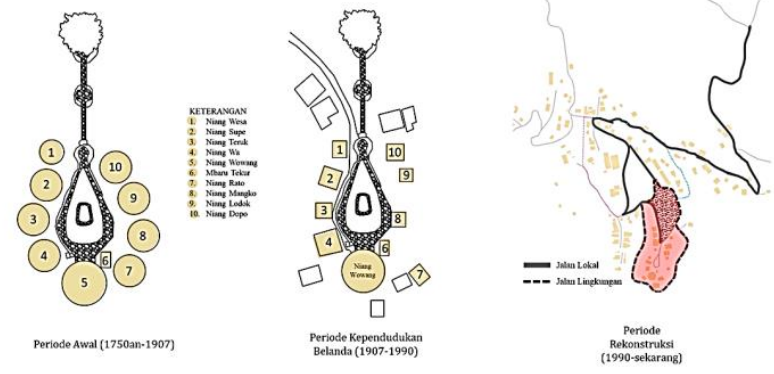

Figure 4 Todo Village development

In terms of typology, houses in the early period were circular with conical roofs. The material used is natural materials such as palm fiber and wood. It continued until the reconstruction period, where fibers were difficult to find around settlements. When the modernization comes in, there was a change in the use of materials such as zinc roofs, cement floors, walls, and modern doors. There were also changes in building shape. The initially circular plan changed to square and rectangular while the roof has changed from conical into the shape of a saddle, a pyramid, or combination.

Table 1 Difference of architectural element in each Todo Village's periods

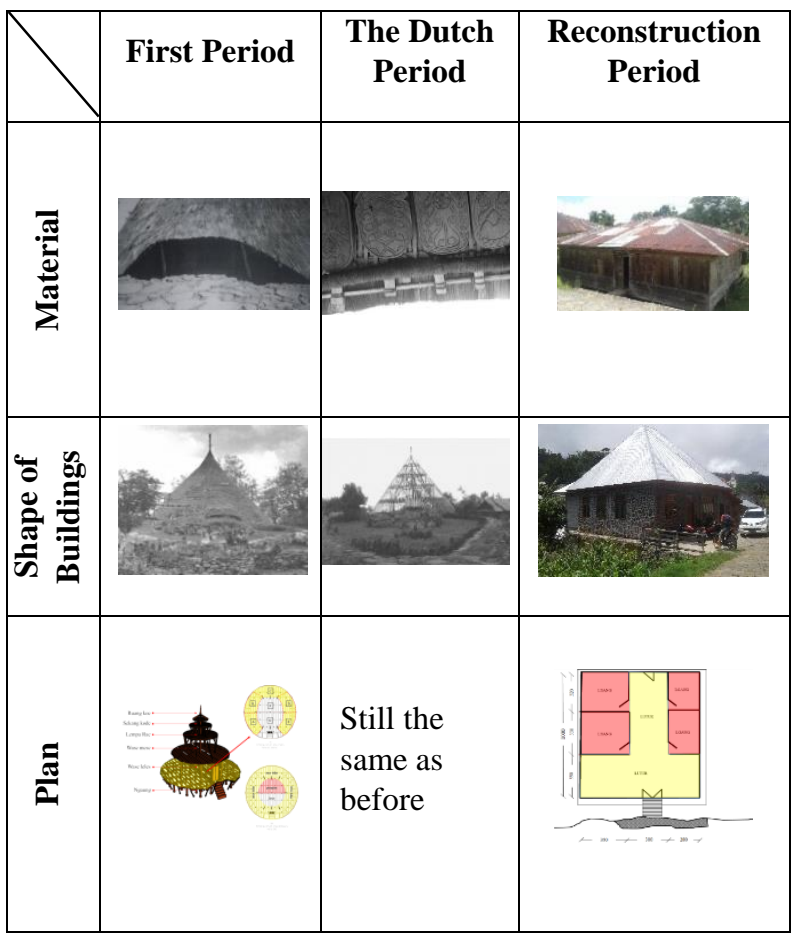

Based on the pattern, in the initial period, the form of a circular settlement surrounded natas and compang. The order reflects the lifestyle of the people who uphold togetherness, which is marked by the existence of natas and compang as a binding space between elements. Mbaru Niang order has a special provision that is must deal with the entrance to the village and the rag. Other houses besides Mbaru Niang are linear on the right and left side of Mbaru Niang. In this case, Mbaru Niang means the unity of a traditional village (beo adak). In the next period, settlements developed following contour conditions.

The pattern depicted in Niang Wowang is a reflection of the pattern of buildings in settlements that surround the outer space. If, in the previous period, traditional buildings surrounded natas and compang as outer space, then during the reconstruction period, houses resulting from the development of settlements were oriented towards boa and the field as outer space.

Buildings in Todo Village in the early period functioned as government offices in the era of the outrage. When the Dutch entered, the building function changed to be a place 
of residence due to a change in policy. However, in these two periods, Mbaru Niang was still used as a symbol of Adak Todo's power. In the next period, Mbaru Niang did not function as it should, while the residential function was transferred to modern buildings.

In the early period, the settlement hierarchy was evident. It can be seen in the height of the contour shown by the location of the road as a public area at the lowest level, residential settlements are at a higher contour, and the highest hierarchy is in the compang and boa as a place of offering to ancestors (Mori). However, after the entry of Catholicism in Kampung Todo in the 1920s, the belief in animism-dynamism disappeared. The highest hierarchy, which was originally in the compang and natas shifted into a parish church.

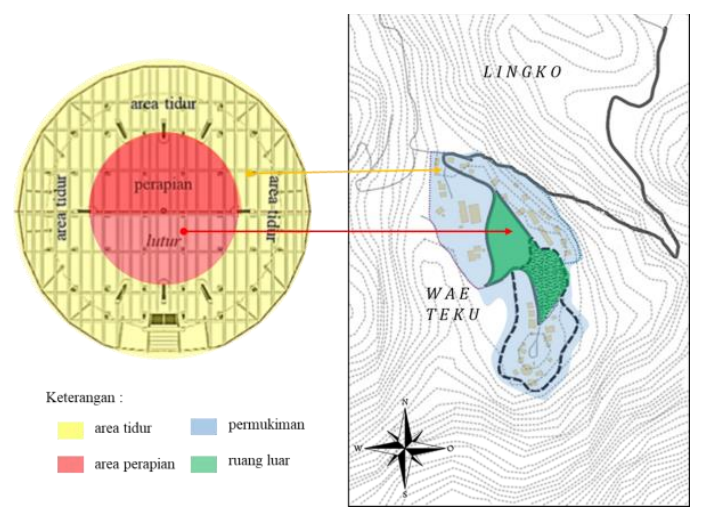

Figure 5 Settlement's orientation

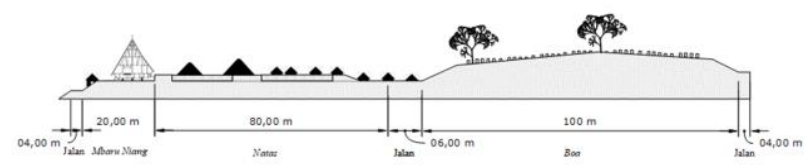

Figure 6 Hierarchy in the first period and the Dutch settlement

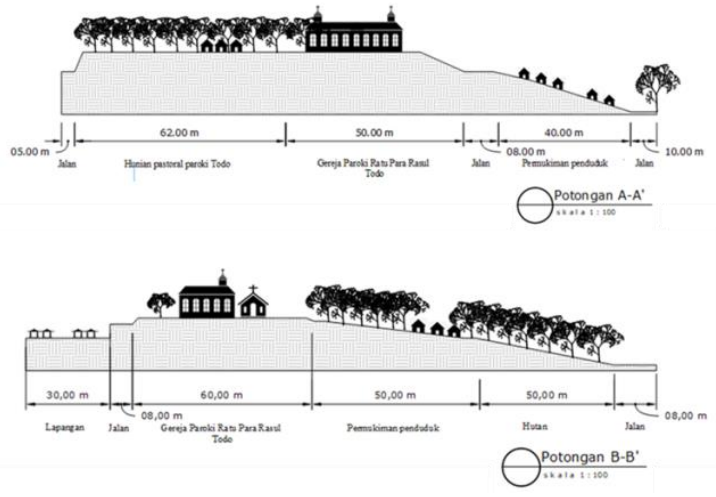

Figure 7 Hierarchy at the reconstruction period

\section{CONCLUSION}

Based on the discussion and analysis explained in the previous chapter, several findings related to changes in the architecture of Kampung Todo settlement began from the initial period to the reconstruction period, namely:

a. Stylistic System:

- The form of settlement has changed according to the development of settlements, land availability, and contour conditions. Changes of the building shape can be seen from the roof, which was initially a conical roof developed into a gable roof, as well as a combination of pyramid and saddle.

- The settlement dimension is changing. During the Dutch period, houses that were initially large were converted into small houses, then during the reconstruction period adapted to general housing conditions.

b. Physical System:

- The function of settlements has changed, buildings in the Todo village in the early period had the function as government offices. When the Dutch entered, the building function changed into a residential due to a change in policy. However, in these two periods, Mbaru Niang was still used as a symbol of Adak Todo's power even though in the Dutch period, the function had already been lost. In the next period, Mbaru Niang did not function as it should, while the residential function was transferred to modern buildings.

- In terms of material, fibers are currently difficult to obtain. The floor, which used to be in the form of a wooden board, changed into cement. Likewise with the wall, which was initially made of wood, is now replaced by brick. It is due to the prohibition of free felling of trees issued by the local government. The use of cement is also applied as a solution to building humidity caused by high rainfall in Kampung Todo.

c. Spatial System:

- At the beginning of its formation, Kampung Todo has a circular pattern surrounding natas. Over time, these settlements grew wider.

- Settlement orientation initially directed at Natas and Ragged, but now oriented to outdoor spaces such as Boa, Field, and Natas.

- The hierarchy of space also changes. Initially, the highest hierarchy was in the rag as a binding between the society with the ancestors. Nevertheless, now the hierarchy is replaced by the existence of the church. Hierarchical changes are influenced by the socio-cultural factors of society. 


\section{REFERENCES}

[1] Toda, D. N. Manggarai Mencari Pencerahan Historiograf, 1999.

[2] Erb, M. Contested Time and Place: Constructions of Historical Manggarai (Western Flores, Indonesia). Journal of Southeast Asian, pp. 47-77, 1997.

[3] Sari, I. K. Perubahan Karakter Arsitektur Permukiman Kampung Beting Kota Pontianak, Kalimantan Barat.

Langkau Betang, 62, 2014. 